\title{
KEKERASAN DI DUNIA MAYA: SURVEY TERHADAP SISWA SD DI KABUPATEN SLEMAN
}

\author{
M. Ragil Kurniawan ${ }^{1)}$, Arini Rizqy Karimah ${ }^{2)}$, \& Dholina Inang Pambudi ${ }^{3)}$ \\ 1,2,3) PGSD Universitas Amad Dahlan \\ Email: ragil.kurniawan@pgsd.uad.ac.id;
}

\begin{abstract}
Abastract: This study aims to describe students' perceptions, forms of violence, and factors that cause violence in cyberspace towards elementary students in Sleman Regency. This research uses survey research with quantitative approach. The population in this study was students of Muhammadiyah Elementary School in Sleman Regency. The results showed that students' perceptions of violence in cyberspace were positive, but in reality students still experienced and committed violence in cyberspace. Various forms of violence in cyberspace that are most experienced by students, are: got an angry message on social media $(11 \%)$, got annoying messages on social media $(10 \%)$, get a rude photo on social media $(9,8 \%)$. Meanwhile, the forms of violence in cyberspace that are most often carried out by students are: send a message that makes other people angry on social media $(11,6 \%)$, send messages that disturb other people on social media $(11,2 \%)$, comment on other people's photos or videos with socially abusive words $(11,2 \%)$. The factors that cause violence in cyberspace towards the biggest elementary school students in Sleman Regency are: because of fad $(12,1 \%)$ and other reasons $(11,3 \%)$.
\end{abstract}

Keyword: violence, cyberspace, elementary school student

\begin{abstract}
Abstrak: Penelitian ini bertujuan untuk mendeskripsikan persepsi siswa, bentuk-bentuk kekerasan, dan faktor-faktor penyebab kekerasan di dunia maya terhadap siswa SD di Kabupaten Sleman. Penelitian ini menggunakan jenis penelitian survei dengan pendekatan kuantitatif. Populasi dalam penelitian ini adalah siswa SD Muhammadiyah se-Kabupaten Sleman. Hasil penelitian menunjukkan bahwa persepsi siswa tentang kekerasan di dunia maya adalah positif, tetapi dalam kenyataannya siswa masih mengalami dan melakukan kekerasan di dunia maya. Bentuk-bentuk kekerasan di dunia maya yang paling banyak dialami siswa yaitu mendapat pesan yang membuat marah dimedia sosial (11\%), mendapat pesan yang mengganggu dimedia sosial $(10 \%)$, dan mendapat foto tidak sopan dimedia sosial $(9,8 \%)$. Sedangkan, bentuk-bentuk kekerasan di dunia maya yang paling banyak dilakukan siswa kelas yaitu mengirim pesan yang membuat orang lain marah dimedia sosial $(11,6 \%)$, mengirim pesan yang mengganggu orang lain dimedia sosial $(11,2 \%)$, dan mengomentari foto atau video orang lain dengan kata yang tidak menyenangkan dimedia sosial $(11,2 \%)$. Faktor-faktor penyebab kekerasan di dunia maya terhadap siswa kelas V di Kabupaten Sleman terbesar adalah karena iseng $(12,1 \%)$, benci atau jengkel $(12,1 \%)$ dan alasan yang lainnya $(11,3 \%)$.
\end{abstract}

Kata Kunci: Kekerasan, Dunia Maya, Siswa Sekolah Dasar

\section{PENDAHULUAN}

Pada masa era digital seperti saat ini, salah satu kemudahan bagi masyarakat Indonesia yaitu dapat mengakses jaringan internet dengan cepat. Semakin canggihnya teknologi digital masa kini mempengaruhi tingkat perubahan terhadap kehidupan masyarakat, berbagai jenis teknologi digital banyak bermunculan seiring dengan kemajuan zaman. Berdasarkan hasil riset "Netizen Indonesia 2010" yang dilakukan oleh Markplus Insight terdapat beragam pengguna internet yang dikelompokkan menjadi tiga. Pertama, negatif $(37,8 \%)$ dimana pengguna internet memandang bahwa internet banyak mengandung sisi menyimpang dan kurang baik. Kedua, moderat (32,9\%) dimana pengguna internet yang memakai sesuai kebutuhannya dan internet sebagai sumber informasi serta hiburan. Ketiga, positif $(29,9 \%)$ dimana pengguna internet tidak dapat dipisahkan dari kehidupan 
agar tidak ketinggalan zaman (Rusdianto, 2014: 54).

Dunia ini semakin canggih dengan perkembangan teknologi yang berjalan begitu cepat. Setiap perkembangan dan seiring berjalannya waktu, muncul satu generasi baru yang memiliki pola pikir dan karakteristik yang berbeda-beda. Generasi Z adalah generasi yang lahir pada tahun (1995-2010) disebut juga iGeneration atau generasi internet. Generasi Z mampu menjalankan tugas ganda dalam satu waktu dan secara bersamaan (multi tasking) seperti mengoperasikan media sosial menggunakan ponsel, mencari informasi menggunakan PC (personal computer), dan mendengarkan musik menggunakan headset. Apapun yang dilakukan oleh generasi $\mathrm{Z}$ kebanyakan berhubungan dengan dunia maya. Sejak kecil generasi ini sudah mengenal teknologi serta akrab dengan gadget yang berpengaruh terhadap kepribadiannya secara tidak langsung (Bencsik, dkk dalam Putra, 2016: 130).

Generasi $\mathrm{Z}$ yang paling tampak menguasai teknologi dan informasi yang pesat. Teknologi dan informasi tidak dapat dipisahkan dari kehidupan generasi $\mathrm{Z}$ karena mereka lahir di mana akses terhadap informasi khususnya internet menjadi budaya global, sehingga fenomena tersebut dapat berpengaruh terhadap pola pikir dan tujuan hidup mereka. Internet merupakan salah satu contoh media yang efektif dalam memperoleh dan membagikan informasi tanpa hambatan jarak maupun waktu untuk berinteraksi satu sama lain di seluruh dunia. Walaupun tanpa bertatap muka, seseorang dapat berkomunikasi dengan orang lain menggunakan kecanggihan teknologi.

Saat ini usia siswa sekolah dasar berkisar 6 tahun sampai 12 tahun, sehingga siswa sekolah dasar dapat dikategorikan berada pada generasi $\mathrm{Z}$. Perkembangan teknologi sangat berpengaruh terhadap kehidupan siswa sekolah dasar yang salah satunya yaitu berkomunikasi, mereka pun juga berkembang seiring dengan majunya teknologi. Masa-masa perkembangan siswa sekolah dasar adalah bermain dengan teman sebaya, mereka akan menghabiskan waktu bermain di sekolah atau lingkungan sekitarnya. Terdapat beberapa fenomena-fenomena tidak menyenangkan yang dialami siswa sekolah dasar seperti diejek, dihina, atau dipojokkan oleh teman sebayanya dalam lingkungan sekolah. Siswa dapat memahami dan mempraktikkan hal serupa melalui apa yang dilihat secara langsung atau kemudahan mengakses internet seperti menonton adegan perkelahian di media sosial.

Situs merdeka.com merilis berita pada 9 Agustus 2017 tentang meninggalnya siswa sekolah dasar kelas II di Sukabumi akibat berkelahi dengan temannya. Komisioner KPAI Bidang Pendidikan berkomentar, kasus kematian siswa tersebut menunjukkan sekolah aman dan nyaman bagi anak ternyata masih jauh dari harapan. Banyaknya kasus-kasus kekerasan di sekolah yang diterima KPAI, menjadi kesempatan bagi Kemdikbud RI untuk meninjau kembali kebijakan menambah lamanya berada di sekolah. Karena ternyata sistem pengawasan yang lemah di banyak sekolah telah membuat sekolah tidak lagi menjadi tempat yang aman dan nyaman bagi anak.

Surat Kabar Harian Kompas pada 7 November 2017 memberitakan bahwa Komisi Perlindungan Anak Indonesia (KPAI) mencatat sepanjang tahun 2011 sampai September 2017, terdapat 2.778 kasus kekerasan yang terjadi di sekolah. Kasus yang terungkap akhir-akhir ini adalah pemukulan siswa oleh seorang dewasa di sebuah kelas dalam video yang tersebar viral. Hingga kasus kekerasan tersebut mendapat perhatian yang serius dari Wakil Presiden Yusuf Kalla untuk meminta supaya ada verifikasi sumber, lokasi, dan waktu kejadian. Kendati 
terdapat Undang-Undang Republik Indonesia Nomor 35 Tahun 2014 tentang Perlindungan Anak, tetapi dalam kenyataannya saat ini kasus kekerasan anak di lingkungan sekolah masih marak terjadi. KPAI berharap pemerintah mempercepat penerbitan peraturan presiden sehingga bisa menjadi pijakan untuk mewujudkan sekolah ramah anak.

Melalui situs metrotvnews.com pada 23 Desember 2017, organisasi khusus mengadvokasi kasus kekerasan terhadap perempuan dan anak yang mencatat setiap tahun terdapat kurang lebih 300 kasus dari tahun 2010 hingga 2017, yakni 321 kasus pada tahun 2010, 347 kasus pada tahun 2011, 303 kasus pada tahun 2012, 326 kasus pada tahun 2013, 252 kasus pada tahun 2014, 322 kasus pada tahun 2015, 325 kasus pada tahun 2016, dan 287 kasus pada Januari sampai 6 Desember 2017 di Kabupaten Sleman. Dengan demikian, keseluruhan kasus kekerasan pada tahun 2017 membuat Kabupaten Sleman menduduki peringkat pertama dengan jumlah kasus kekerasan tertinggi, disusul Kota Yogyakarta, Bantul, Gunungkidul, dan Kulonprogo.

Berdasarkan kasus-kasus tersebut, dapat diketahui ternyata kekerasan yang dialami siswa dalam berbagai bentuk kekerasan masih banyak dilakukan di lembaga pendidikan seperti sekolah, mulai dari kekerasan ringan hingga kekerasan berat. Terdapat kekerasan secara fisik dan nonfisik yang dapat menimbulkan kesakitan bagi korban secara mental maupun jiwa seperti perasaan cemas, takut, tidak percaya diri dan lain sebagainya. Mencermati kondisi tersebut, perilaku kekerasan memiliki dampak negatif yang harus ditanggapi dengan serius sehingga tidak memakan korban lagi.

Menurut Djamal (2016: 83) kekerasan adalah "menggambarkan perilaku menyakiti orang lain baik secara fisik maupun nonfisik atau perilaku yang dilakukan dengan maksud untuk melukai orang lain baik fisik maupun psikis di mana orang yang menjadi korban tidak menginginkan." Kekerasan secara fisik dapat menghasilkan luka pada bagian tubuh seperti luka goresan, memar, luka bagian dalam dan lain sebagainya. Kekerasan secara psikologis juga dapat mengakibatkan tingkat kepercayaan diri yang rendah sampai depresi dalam jangka panjang hingga menimbulkan trauma bagi korban. Seseorang dianggap sebagai korban kekerasan apabila mendapatkan tindakan negatif, tidak menyenangkan, dan tidak diinginkan dari satu orang atau lebih yang dilakukan secara sengaja untuk mencapai keinginan tertentu. Biasanya target korban kekerasan pada anak cenderung memilih yang pendiam, memiliki fisik yang lemah, mudah terintimidasi atau ditindas, dan memiliki sedikit teman.

Kekerasan yang dialami anak pada dunia nyata seperti lingkungan sekolah atau di lingkungan sekitarnya, tidak menutup kemungkinan berpotensi terbawa atau terjadi kekerasan di dunia maya. Berdasarkan hasil jurnal Rahayu (2012: 23) kekerasan di dunia maya dapat menimbulkan seseorang merasa diintimidasi, diperlakukan tidak manusiawi, merasa tertekan, penghinaan terus menerus, atau merasa dipojokkan bahkan dipermalukan yang dapat dilihat oleh seluruh orang di dunia. Dampak negatif kekerasan di dunia maya ternyata lebih menyakitkan daripada kekerasan di dunia nyata karena dilihat dari faktor korban depresi yang lebih tinggi. Hingga hal yang lebih mengerikan yaitu mengakhiri hidupnya dengan bunuh diri karena tidak kuat lagi menahan diri.

Sekolah merupakan lembaga pendidikan formal terstruktur dan berjenjang yang terdiri dari pendidikan dasar, pendidikan menengah, dan pendidikan tinggi, dimana siswa dapat memperoleh ilmu dan mengembangkan kemampuan yang tidak terbatas pada kegiatan di dalam kelas saja. Sekolah diharapkan mampu mewujudkan salah 
satu cita-cita bangsa Indonesia yaitu mencerdaskan kehidupan bangsa. Salah satu cara untuk mewujudkan cita-cita bangsa Indonesia yaitu membentuk kondisi dan suasana pembelajaran di sekolah yang menyenangkan bagi siswa, agar mampu mengembangkan semua potensi yang dimilikinya. Tidak dapat dipungkiri, sekolah sesungguhnya juga sebagai tempat untuk mengembangkan perilaku sopan santun, bebas menyampaikan pendapat, dan tidak adanya diskriminasi kepada seluruh warga sekolah terutama siswa.

Usia siswa sekolah dasar mulai mengenal perbedaan perilaku atau perbuatan yang benar dan salah atau baik dan buruk. Siswa sekolah dasar mulai mengerti juga dalam pengungkapan katakata kasar yang tidak diterima oleh orang-orang dalam lingkungan sekitarnya. Dalam perkembangan sosial, siswa mengalami hubungan atau interaksi dengan keluarga hingga perluasan hubungan dengan teman sebaya atau menjalin hubungan dengan orang lain di dunia maya. Bisa jadi siswa mulai apatis dengan lingkungan sekitarnya karena lingkungan sosialnya saat ini lebih banyak pada media sosial. Jika siswa tidak diarahkan dan diawasi secara teliti melalui peran orang tua atau guru di sekolah, dikhawatirkan pergaulannya akan menjadi salah (Yusuf dan Sugandhi, 2014: 63).

Orangtua maupun guru di sekolah tidak bisa hanya melarang anak untuk tidak menggunakan media sosial, karena saat ini mereka bukan berada pada generasi yang tidak menggunakan media elektronik. Maraknya pengguna smartphone dan internet, membuka peluang perilaku kekerasan di dunia maya atau cyberbullying terjadi secara terus menerus ataupun berulang-ulang. Jika tidak dimulai penanganan dari sekarang maka memungkinkan akan banyaknya fenomena-fenomena kekerasan yang terjadi di lingkungan sekolah.
Antisipasi tentang kekerasan di dunia nyata yang berpeluang bergeser ke dunia maya terhadap siswa sekolah dasar di Kabupaten Sleman sangatlah penting. Pihak sekolah dapat memulai langkah awal untuk menentukan kebijakankebijakan terkait pengawasan. Dapat ditinjau dari segi aktivitas interaksi warga sekolah melalui media sosial dan aktivitas yang mengandung unsur kekerasan pada siswa.

Berdasarkan uraian sebelumnya, tujuan peneliti adalah untuk mengetahui persepsi siswa, bentuk-bentuk serta faktor-faktor penyebab kekerasan di dunia maya terhadap siswa SD Muhammadiyah di Kabupaten Sleman.

\section{METODE PENELITIAN}

Penelitian ini memilih menggunakan jenis penelitian survei dengan pendekatan kuantitatif. Populasi dalam penelitian ini adalah siswa SD Muhammadiyah se-Kabupaten Sleman dengan jumlah 2.362 siswa. Penentuan sampel dalam penelitian ini dilakukan dengan cara stratified random sampling. Didapatkan sampel penelitian adalah 262 siswa kelas V yang berasal dari 8 SD Muhammadiyah di Kabupaten Sleman.

Pada tahap pertama dalam pemilihan sampel yaitu dengan mengklasifikasi strata seluruh SD Muhammadiyah di Kabupaten Sleman yang memiliki akreditasi A, B dan C yang berjumlah 78 sekolah. Tahap kedua, menentukan jumlah sampel dalam setiap strata sekolah akreditasi A, B dan C. Tahap ketiga, memilih sampel dari setiap data kelompok sekolah dasar akreditasi A, B dan C secara acak oleh peneliti.

Alat untuk mengukur instrumen menggunakan kuisioner dengan jenis kuisioner tertutup. Kuisioner ini terdiri dari 33 pernyataan dan pertanyaan yang telah disediakan peneliti, sehingga responden hanya memilih jawaban yang telah tersedia. Peneliti menggunakan pengujian validitas konstruk dan pengujian realibitas internal consistency 
dengan bantuan komputer. Kuisioner diujicobakan kepada 40 orang siswa di sekolah selain sampel.

Teknik analisis data penelitian ini menggunakan statistik deskriptif. Data dianalisis menggunakan bantuan Statistical Package for the Social Science (SPSS) dan Microsoft Excel untuk mendapatkan data mengenai persepsi, bentuk-bentuk kekerasan, dan faktorfaktor penyebab kekerasan di dunia maya terhadap siswa SD di Kabupaten Sleman.

\section{HASIL DAN PEMBAHASAN}

Hasil dalam penelitian ini yaitu mencakup persepsi siswa tentang dampak media sosial dan kekerasan di dunia maya, bentuk-bentuk kekerasan, dan faktor-faktor penyebab kekerasan di dunia maya.

\section{Deskripsi Hasil Persepsi Siswa}

Persepsi siswa tentang kekerasan di dunia maya dalam penelitian ini terdiri dari 3 hal, yaitu dampak yang diakibatkan media sosial, aktifitas menghina orang lain di media sosial dan melakukan kekerasan melalui media sosial.

Sesuai data yang telah diambil berikut data persepsi tentang media sosial memiliki dampak positif bagi pengguna. sebanyak $13,7 \%$ responden mengaku "sangat setuju" jika medsos memiliki dampak positif. Sebanyak 42,7\% responden mengaku "setuju" tentang dampak positif medsos. Sedangkan sebanyak 33,2\% responden menyatakan "ragu-ragu" tentang dampak positif medsos. Serta terdapat sebanyak $10,3 \%$ responden yang menyatakan tidak setuju/sangat tidak setuju dengan dampak positif yang dibawa media sosial. Sebagaimana ditampilkan dalam diagram lingkar berikut.

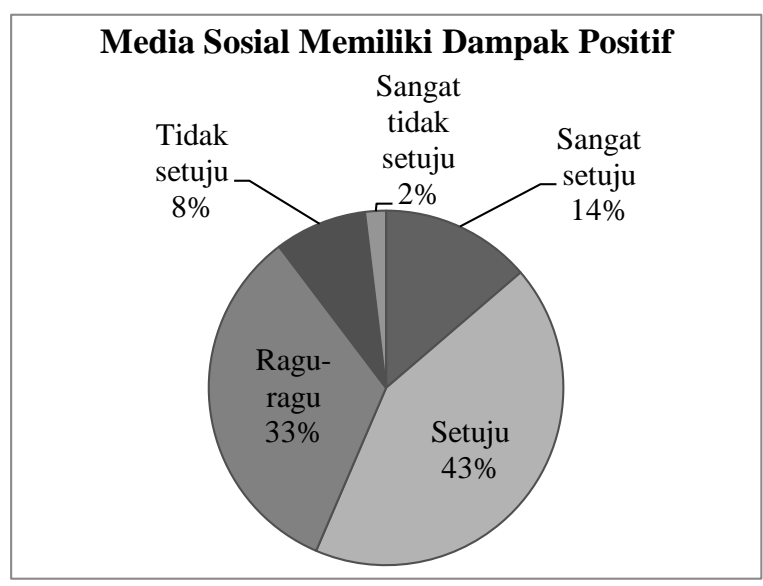

Gambar I. Diagram media sosial memiliki dampak positif

Hasil ini sesuai dengan penelitian Rifauddin (2016: 37) yang menyatakan bahwa internet dapat memudahkan penggunanya dalam mendorong munculnya berbagai media sosial seperti facebook, twitter, instagram, dan sebagainya untuk bertukar informasi dan berkomunikasi dengan orang lain tanpa harus bertatap muka satu sama lain. Media sosial memiliki berbagai kelebihan yaitu konten dapat dibagikan kepada banyak orang, konten dapat diterima secara online dalam waktu lebih cepat dan bisa juga tertunda penerimaannya, menjadikan penggunanya sebagai kreator dan aktor untuk beraktualisasi diri, terdapat sejumlah aspek fungsional seperti identitas, percakapan (interaksi), berbagi (sharing), kehadiran (eksis), hubungan (relasi), reputasi (status) dan kelompok (grup).

Yang kedua, persepsi siswa tentang boleh atau tidaknya menghina orang lain di media sosial. "sangat setuju" Sebanyak $0,8 \%$ responden mengaku setuju/ sangat setuju diperbolehkannya menghina orang di media sosial. Sebanyak 1,9\% responden mengaku ragu-ragu apakah diperbolehkan atau tidak melakukan penghinaan di media social. Namun demikian, sebanyak $97,3 \%$ responden mengaku tidak/sangat tidak setuju dengan aktifitas menghina orang lain di media 
sosial. Sebagaimana ditampilkan dalam diagram lingkar berikut.

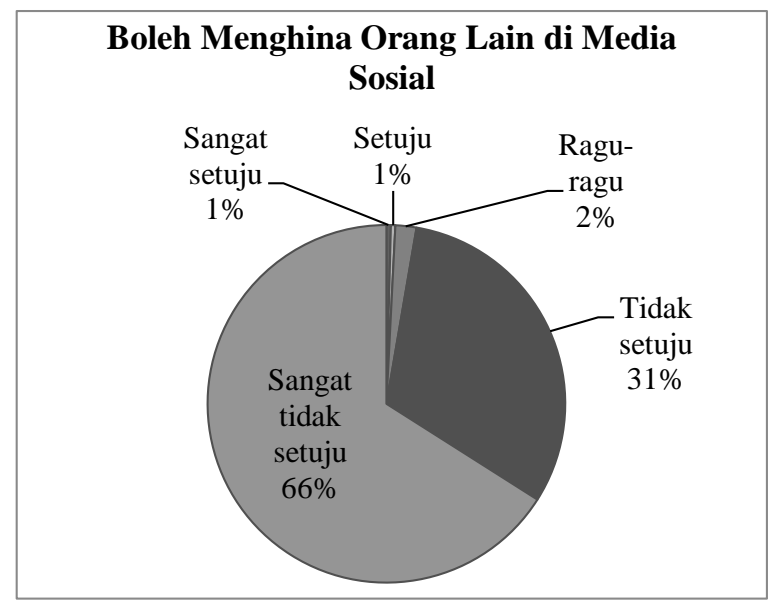

Gambar II. Diagram boleh menghina orang lain di media sosial

Yang ketiga, persepsi tentang kewajaran melakukan kekerasan di dunia maya. Sebesar (2\%), yang mengaku wajar melakukan kekerasan di media sosial. Sebanyak 10,3\% responden mengaku ragu-ragu dengan tindakan tersebut. Namun sebanyak 87,7\% responden mengaku tidak/sangat tidak setuju dengan aktifitas melakukan keekrasan di dunia maya. Sebagaimana ditampilkan dalam diagram lingkaran berikut.

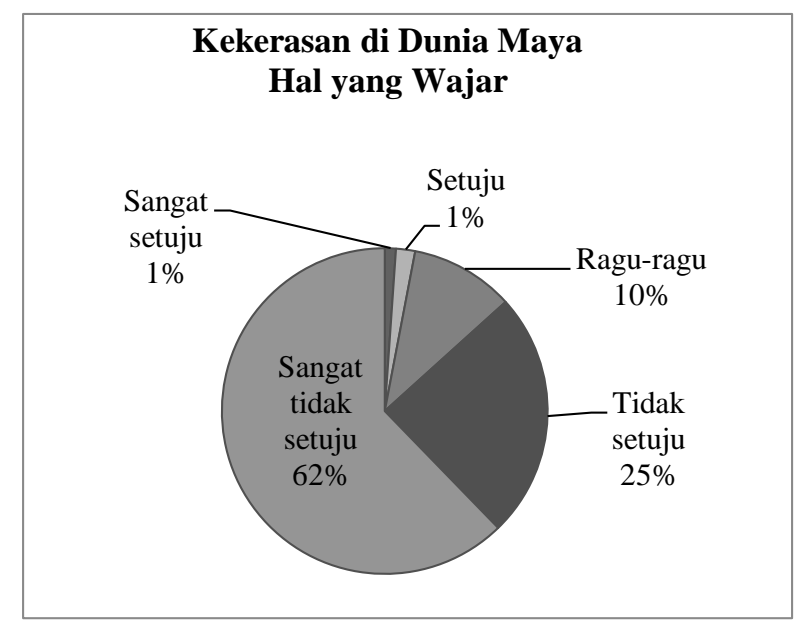

Gambar III. Diagram kekerasan di dunia maya hal yang wajar

\section{Deskripsi Hasil Bentuk-Bentuk \\ Kekerasan di Dunia Maya}

Bentuk kekerasan di dunia maya berdasarkan hasil survey diantaranya berupa: a) mendapat pesan yang membuat marah dimedia sosial, b) mendapat pesan yang mengganggu dimedia sosial, c) disebar keburukan korban dimedia sosial, d) berpura-pura menjadi orang lain dan mengirimkan pesan negatif kepada korban, e) disebar rahasia korban dimedia sosial, $f$ ) membaca status orang lain yang mengejek korban dimedia sosial, g) dikeluarkan orang lain dari grup online, h) dikomentari foto/video dengan kata tidak menyenangkan dimedia sosial, i) mendapatkan pesan tidak sopan dimedia sosial yaitu, j) mendapat foto tidak sopan dimedia sosial.

Berdasarkan hasil penelitian menunjukkan fenomena siswa sekolah dasar sebagai korban kekerasan di dunia maya. Secara terinci, data menunjukkan bahwa sangat sering $(2 \%)$, sering $(4,1 \%)$, kadang-kadang $(10,9 \%)$, jarang $(24,2 \%)$, dan tidak pernah $(58,8 \%)$ menjadi korban kekerasan di dunia maya. Berdasarkan data yang dialami siswa dalam bentuk kekerasan di dunia maya dapat ditampilkan dalam diagram lingkaran berikut.

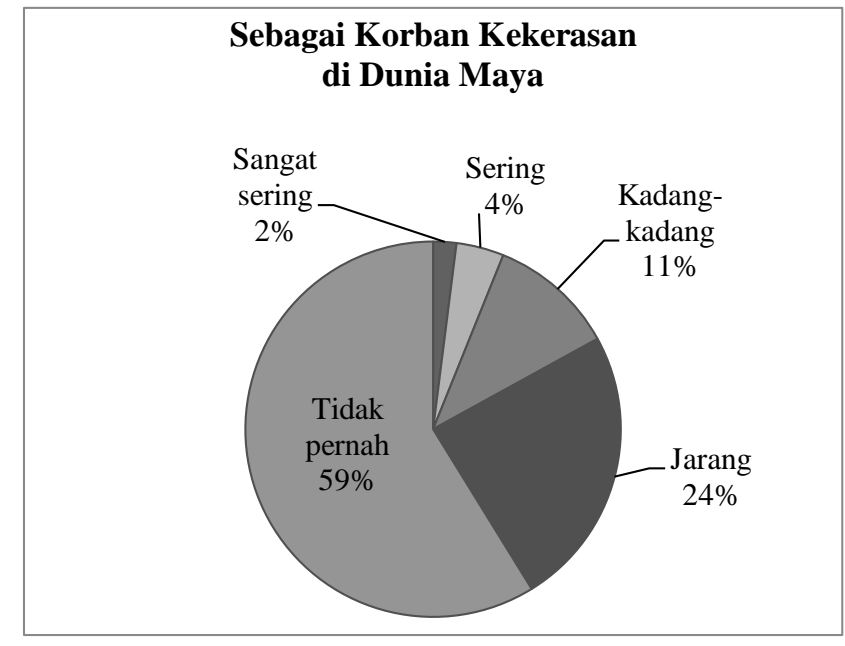

Gambar IV. Diagram sebagai korban kekerasan di dunia maya

Selanjutnya, hasil penelitian menunjukkan fenomena siswa sekolah dasar sebagai pelaku kekerasan di dunia maya. Secara terinci, data menunjukkan bahwa sangat sering $(0,9 \%)$, sering $(1,4 \%)$, kadang-kadang $(5,3 \%)$, jarang 
$(12,9 \%)$, dan tidak pernah $(79,4 \%)$ menjadi pelaku kekerasan di dunia maya. Berdasarkan data yang dilakukan siswa dalam bentuk kekerasan di dunia maya dapat ditampilkan dalam diagram lingkaran berikut.

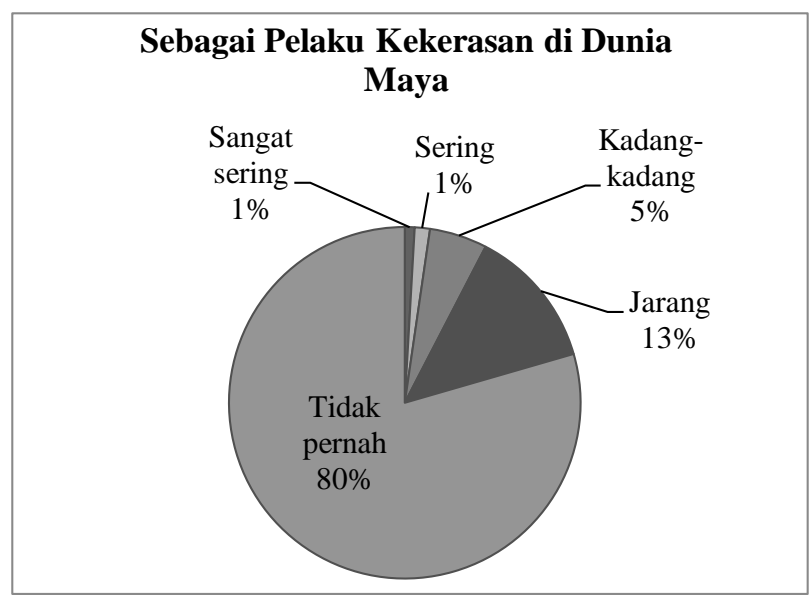

Gambar V. Diagram sebagai pelaku kekerasan di dunia maya

Berdasarkan data yang telah didapatkan, bentuk-bentuk kekerasan di dunia maya yang dialami siswa di Kabupaten Sleman yaitu mendapatkan pesan yang membuat marah dimedia sosial $(11 \%)$, mendapatkan pesan yang mengganggu dimedia sosial (10\%), mendapatkan foto tidak sopan/pornografi dimedia sosial $(9,8 \%)$, mendapatkan pesan tidak sopan/pornografi dimedia sosial $(9,6 \%)$, dan mendapat video tidak sopan/pornografi dimedia sosial $(9,5 \%)$. Selanjutnya, dikeluarkan dari grup online di media sosial $(9,3 \%)$, diejek dimedia sosial $(8,7 \%)$, dikomentari foto/video dengan kata tidak menyenangkan dimedia sosial $(8,5 \%)$, disebar keburukan dimedia sosial $(8,3 \%)$, disebar rahasia dimedia sosial $(8,1 \%)$, dan berpura-pura serta mendapat pesan negatif dimedia sosial $(7,3 \%)$. Sebagaimana dalam diagram batang tentang bentuk-bentuk kekerasan di dunia maya yang dialami siswa sekolah dasar berikut.

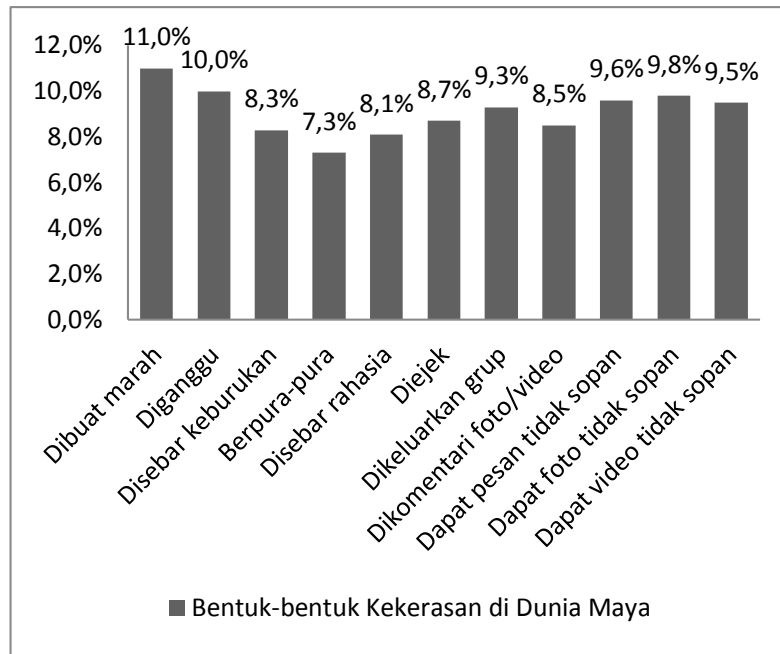

Gambar VI. Diagram bentuk-bentuk kekerasan di dunia maya yang dialami

Sedangkan,

bentuk-bentuk kekerasan di dunia maya yang dilakukan siswa kelas V SD Muhammadiyah di Kabupaten Sleman yaitu mengirim pesan yang membuat orang lain marah dimedia sosial (11,6\%), mengirim pesan yang mengganggu orang lain dimedia sosial $(11,2 \%)$, mengomentari foto atau video orang lain dengan kata yang tidak menyenangkan dimedia sosial $(11,2 \%)$, mengeluarkan orang lain dari grup online dimedia sosial $(10,5 \%)$, dan menyebarkan rahasia orang lain dimedia sosial $(10,1 \%)$. Selanjutnya, mengejek dimedia sosial $(9,8 \%)$, mengirim pesan tidak sopan/pornografi dimedia sosial $(9,5 \%)$, menyebarkan keburukan dimedia sosial $(9 \%)$, berpura-pura menjadi orang lain serta mengirim pesan negatif dimedia sosial $(8,7 \%)$, dan mengirimkan foto tidak sopan/pornografi dimedia sosial $(8,5 \%)$. Sebagaimana dalam diagram batang tentang bentuk-bentuk kekerasan di dunia maya yang dilakukan siswa sekolah dasar berikut. 


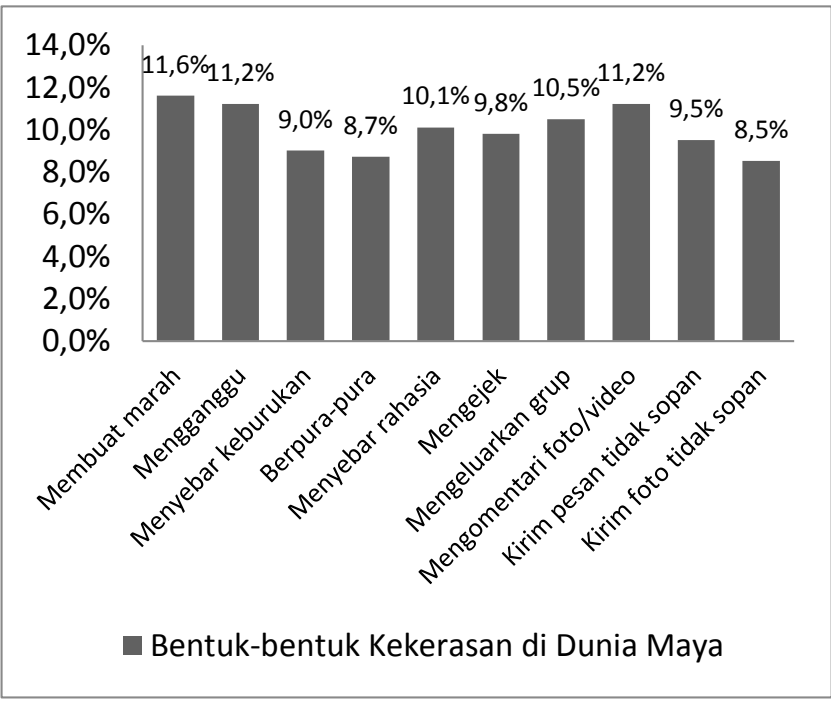

Gambar VII. Diagram bentuk-bentuk kekerasan di dunia maya yang dilakukan

Penelitian ini menghasilkan persentase siswa di Kabupaten Sleman yang mengalami dan melakukan berbagai bentuk-bentuk kekerasan di dunia maya dengan tingkatan sangat sering, sering, kadang-kadang, jarang, dan tidak pernah. Pada setiap tingkatan tersebut terdapat siswa yang mengalami dan melakukan kekerasan di dunia maya walaupun dengan persentase yang berbeda-beda. Hal tersebut menunjukkan adanya aktivitas tindakan kekerasan di dunia maya yang dialami dan dilakukan oleh siswa kelas V SD Muhammadiyah di Kabupaten Sleman. Upaya mengatasi dan penanganan bentuk-bentuk kekerasan di dunia maya penting dilakukan mengingat peran siswa sekolah dasar sebagai generasi penerus bangsa.

Selaras dengan kajian penelitian yang dilakukan Sartana dan Afriyeni (2017: 36) memperlihatkan bahwa kasus perundungan maya di Indonesia, cenderung tinggi dibandingkan pada tempat lain. Maka pihak-pihak terkait yang berpengaruh terhadap siswa perlu melakukan beragam tindakan preventif untuk menanganinya. Penting juga memberikan penjelasan kepada orang tua dan sekolah mengenai fenomena perundungan maya. Sedikit atau banyaknya siswa yang mengalami atau melakukan perilaku kekerasan di dunia maya harus dihilangkan karena dapat berpotensi menular kepada orang lain.
3. Deskripsi Hasil
Faktor-Faktor

Penyebab Kekerasan di Dunia Maya

Terdapat beragam factor penyebab kekerasan di dunia maya. Hasil dari faktor-faktor penyebab kekerasan di dunia maya di Kabupaten Sleman adalah sebagai berikut: a) karena masalah di rumah. b) karena masalah di sekolah, c) karena masalah teman sebaya. d) karena keisengan, e) karena benci atau jengkel, f) karena balas dendam, g) karena mengikuti teman, h) karena ingin mendapat penghargaan/pengakuan hebat dari orang lain. Sebagai mana terdapat dalam gambit berikut ini.

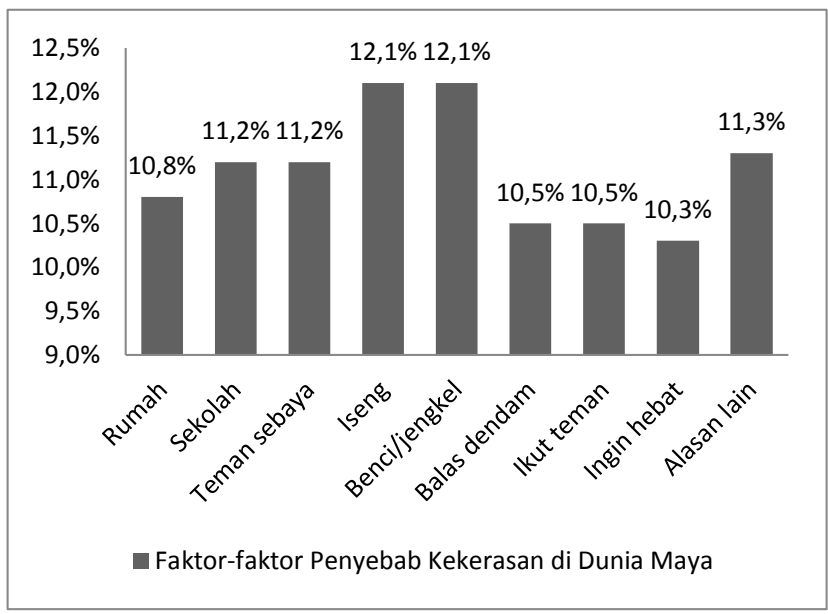

Gambar VIII. Diagram faktor-faktor penyebab kekerasan di dunia maya yang dialami

Berdasarkan data yang pada gamar VIII, ada berbagai faktor-faktor penyebab kekerasan di dunia maya yang dilakukan siswa di Kabupaten Sleman. Faktorfaktor kekerasan di dunia maya yang paling banyak dilakukan siswa yaitu karena iseng $(12,1 \%)$, benci atau jengkel $(12,1 \%)$, alasan yang lainnya $(11,3 \%)$, masalah dengan teman sebaya $(11,2 \%)$, dan masalah di sekolah (11,2\%). Sebagaimana ditampilkan dalam diagram batang berikut.

Penelitian ini sejalan dengan penelitian yang dilakukan oleh Rahayu (2012: 26) kepada siswa yang melakukan cyberbullying melakukan aksi tersebut yaitu (49\%) siswa menjawab untuk iseng 
saja, (36\%) melakukan karena rasa jengkel dan benci terhadap teman, (7\%) menyatakan karena ingin membalas dendam, dan (4\%) karena ikut-ikutan teman yang lain. Seperti bullying tradisional, alasan melakukan cyberbullying kadang sulit untuk ditentukan, kadang-kadang cyberbullying dilakukan sebagai respon terhadap putusnya persahabatan atau suatu hubungan, kadang-kadang dilakukan karena kebencian, dan beberapa kasus online bullying dilakukan sebagai respon terhadap offline bullying.

Alasan lainnya yang berpotensi siswa melakukan kekerasan di dunia seperti penelitian yang dilakukan Sartana dan Afriyeni (2017: 31) menggali tentang alasan pelaku perundungan maya yang sangat beragam. Alasan yang diperoleh yaitu sekedar untuk bercanda, karena ingin balas dendam, karena ciri fisik dan psikis korban, karena tidak diketahui identitasnya, karena marah dengan korban, karena ingin menghibur diri, dan karena tidak bertemu langsung dengan korban. Alasan lainnya adalah untuk membela orang dekat, merasa diabaikan, ingin memberi pelajaran, serta karena internet lebih murah.

Terdapat beberapa data yang menarik dari hasil penelitian diatas. Hasil data menunjukkan bahwa paling banyak siswa memiliki persepsi tidak setuju\&sangat tidak setuju (97\%) terhadap aktifitas menghina orang lain di media sosial. Data lain menyebutkan bahwa sebesar $87,7 \%$ responden siswa memiliki persepsi tidak setuju\&sangat tidak setuju terhadap aktifitas kekerasan di dunia maya. Persepsi yang dihasilkan siswa di Kabupaten Sleman yaitu persepsi positif. Tetapi dalam kenyataannya, dapa data tentang aktifitas kekerasan di dunia maya, masih ada perilaku kekerasan di dunia maya yang secara sadar atau tidak sadar dilakukan oleh siswa. Hasil antara persepsi dengan tindakan siswa dapat berbeda satu sama lain.
Hasil serupa menurut Robbins, persepsi adalah sesuatu proses pandangan yang dialami setiap orang, namun persepsi tidak selalu sama untuk orang yang berbeda meskipun dengan objek yang sama. Menurut Walgito bahwa persepsi terjadi karena faktor internal yaitu diri sendiri dan faktor eksternal yaitu stimulus dan lingkungan. Kedua faktor tersebut saling berinteraksi dalam proses persepsi agar stimulus dapat disadari oleh individu, maka stimulus harus cukup kuat. Apabila stimulus tidak cukup kuat bagaimanapun besarnya perhatian individu, stimulus tidak akan dapat dipersepsi atau disadari oleh individu yang bersangkutan. Maka terdapat batas kekuatan minimal dari stimulus agar dapat menimbulkan kesadaran pada individu (Prabowo dan Firdaus, 2016: 30).

Pembentukan persepsi bagi siswa sekolah dasar saja tidak cukup dalam menghindari perilaku kekerasan di dunia maya. Tetapi perlu diadakannya tambahan pembelajaran edukasi pada tindakan/ praktik pencegahan perilaku kekerasan di dunia maya. Peran orang tua dan komponen sekolah beserta lingkungan sekitar siswa sangat penting dalam perkembangan pola pikir dan tindakan terhadap sesuatu. Perlunya penerapan pendidikan afektif untuk mengaplikasikan atau membiasakan perilaku yang baik bagi siswa sekolah dasar dalam menghindari tindakan kekerasan di dunia maya.

\section{SIMPULAN}

Berdasarkan analisis data yang telah dijabarkan, maka dapat disimpulkan bahwa persepsi siswa sekolah dasar di Kabupaten Sleman tentang kekerasan di dunia maya terhadap media sosial berbeda dengan tindakannya. Hasil penelitian menunjukkan fenomena siswa sekolah dasar sebagai korban kekerasan di dunia maya. Secara terinci, data menunjukkan bahwa sangat sering $(2 \%)$, sering $(4,1 \%)$, kadang-kadang $(10,9 \%)$, 
jarang $(24,2 \%)$, dan tidak pernah $(58,8 \%)$ menjadi korban kekerasan di dunia maya.

Sedangkan, hasil penelitian menunjukkan fenomena siswa sekolah dasar sebagai pelaku kekerasan di dunia maya. Secara terinci, data menunjukkan bahwa sangat sering $(0,9 \%)$, sering $(1,4 \%)$, kadang-kadang (5,3\%), jarang $(12,9 \%)$, dan tidak pernah $(79,4 \%)$ menjadi pelaku kekerasan di dunia maya. Walaupun minoritas perilaku terhadap kekerasan di dunia maya, tetapi ada fenomena kekerasan yang dialami dan dilakukan oleh siswa sekolah dasar. Terdapat faktor internal dan eksternal yang mempengaruhi siswa dalam melakukan perilaku kekerasan di dunia maya.

Jika dilihat dari masing-masing aspek kekerasan di dunia maya terhadap siswa sekolah dasar sebagai berikut.

1. Persepsi siswa tentang kekerasan di dunia maya terhadap media sosial menghasilkan yaitu persepsi positif, tetapi dalam kenyataannya siswa masih mengalami dan melakukan kekerasan di dunia maya.

2. Bentuk-bentuk kekerasan di dunia maya yang dialami siswa adalah mendapatkan pesan yang membuat marah dimedia sosial (11\%), mendapatkan pesan yang mengganggu dimedia sosial (10\%), mendapatkan foto tidak sopan/pornografi dimedia sosial $(9,8 \%)$, mendapatkan pesan tidak sopan/pornografi dimedia sosial $(9,6 \%)$, dan mendapat video tidak sopan/pornografi dimedia sosial $(9,5 \%)$. Selanjutnya, dikeluarkan dari grup online dimedia sosial $(9,3 \%)$, diejek dimedia sosial $(8,7 \%)$, dikomentari foto/video dengan kata tidak menyenangkan dimedia sosial $(8,5 \%)$, disebar keburukan dimedia sosial $(8,3 \%)$, disebar rahasia dimedia sosial $(8,1 \%)$, dan berpura-pura serta mendapat pesan negatif dimedia sosial $(7,3 \%)$. Sedangkan, bentuk-bentuk kekerasan di dunia maya yang dilakukan siswa yaitu mengirim pesan yang membuat orang lain marah dimedia sosial $(11,6 \%)$, mengirim pesan yang mengganggu orang lain dimedia sosial $(11,2 \%)$, mengomentari foto atau video orang lain dengan kata yang tidak menyenangkan dimedia sosial $(11,2 \%)$, mengeluarkan orang lain dari grup online dimedia sosial $(10,5 \%)$, dan menyebarkan rahasia orang lain dimedia sosial $(10,1 \%)$. Selanjutnya, mengejek dimedia sosial $(9,8 \%)$, mengirim pesan tidak sopan/pornografi dimedia sosial $(9,5 \%)$, menyebarkan keburukan dimedia sosial (9\%), berpura-pura menjadi orang lain serta mengirim pesan negatif dimedia sosial $(8,7 \%)$, dan mengirimkan foto tidak sopan/pornografi dimedia sosial $(8,5 \%)$.

3. Faktor-faktor penyebab kekerasan di dunia maya yang paling banyak dialami siswa kelas V di Kabupaten Sleman adalah karena iseng (12,1\%), benci atau jengkel $(12,1 \%)$ dan alasan yang lainnya $(11,3 \%)$.

\section{DAFTAR PUSTAKA}

\section{Jurnal}

Putra, Yanuar Surya. (2016). Theoritical Review: Teori Perbedaan Generasi. Jurnal: Among Makarti, Vol 9 No.18, 128-130.

Rahayu, Flourensia Sapty. (2012). Cyberbullying Sebagai Dampak Negatif Penggunaan Teknologi Informasi. Journal of Information System, Vol 8, Issue 1, 23.

Sartana dan Nelia Afriyeni. (2017). Perilaku Perundungan Maya (Cyberbullying) pada Remaja Awal. Jurnal Psikologi Insight. Vol 1, No.1, 25.

\section{Prosiding}

Prabowo, Sigit Ari dan Firdaus. (2016). Pengaruh Persepsi Tentang Pelaksanaan Pembelajaran Terhadap Hasil Belajar Mahasiswa Jurusan Pendidikan 
Guru Sekolah Dasar IKIP PGRI Madiun. Prosiding dari Seminar Nasional: Optimalisasi Active Learning dan Character Building dalam Meningkatkan Daya Saing Bangsa di Era Masyarakat Ekonomi Asean (MEA). Yogyakarta, Maret 2016: Prodi PGSD dan BK.

\section{Buku}

Yusuf, Syamsu dan Nani M. Sugandhi. (2014). Perkembangan Peserta Didik Matakuliah Dasar Profesi MKDP Bagi Para Mahasiswa Calon Guru di Lembaga. Jakarta: Rajawali Pers.

Djamal. (2016). Fenomena Kekerasan di Sekolah. Yogyakarta: Pustaka Pelajar.

Rusdianto, Ujang. (2014). Cyber CSR A Guide to CSR Communications on Cyber Media. Yogyakarta: Graha Ilmu.

\section{Surat Kabar}

Ina/Eln. "Kekerasan terhadap anak Perlu Perpres Pendidikan Ramah Anak". Kompas, Selasa 7 November 2017. Jakarta. 